\title{
Assessment of Carbon Emission Reduction for Buildings Projects in Malaysia-A Comparative Analysis
}

\author{
Mustafa M. A. Klufallah ${ }^{1}$, Muhd Fadhil Nuruddin ${ }^{2}$, Mohd Faris Khamidi ${ }^{3}$, Nazhatulzalkis Jamaludin ${ }^{4}$ \\ 1,2 Department of Civil Engineering, Universiti Teknologi PETRONAS, 31750 Tronoh, Perak, \\ Malaysia \\ ${ }^{3}$ School of the Built Environment, Heriot-Watt University Malaysia, 62100 Putrajaya, Malaysia \\ ${ }^{4}$ Department of Civil Engineering, Universiti Teknologi PETRONAS, 31750 Tronoh, Perak, Malaysia
}

\begin{abstract}
The Malaysian construction industry significantly contributes as an empowerment to its development vision of 2020 by reducing $40 \%$ of carbon emission. Moreover, this industry accounts as a threat to the environment, not only in terms of consumption of natural resources but also in emitting million tons of carbon emission annually. In fact, Malaysia is categorized the 30th in the world's ranking in carbon emission level. To mitigate the raise of carbon emission level from the buildings construction, several studies identified some of the effective carbon emission assessment tools for construction projects but it is lack of implementation in Malaysia. The green building index (GBI), Malaysian CIB Report has been introduced to assist the construction stakeholders in reducing the level of carbon emission and the impact of buildings on the environment. This paper presents an analysis of carbon emission from housing projects and office buildings in order to identify and quantify the main sources of carbon emission for each project and it proposes environmental friendly materials as replacement for conventional construction materials to achieve the implementation of sustainability in Malaysia.
\end{abstract}

\section{Introduction}

Global warming is increasingly permeating the fabrics of national discourse across many countries globally. The media, government and businesses are not left out in the quest to go green. Increasing amount of carbon emission in the world, if left unchecked, will lead to higher rates of water evaporation and higher earth's surface temperature. Despite current efforts on the part of Malaysian government to curb emissions, Malaysia is ranks $30^{\text {th }}$ in the world for countries that have the largest amount of carbon emission. In terms of sectoral percentage, $24 \%$ of total carbon dioxide comes from the construction sector in the country [1]. In fact, more than one third of total energy use and greenhouse gases (GHGs) emissions come from Buildings construction both in developed and developing countries.

Environmental issues are not only linked to technological or economic activities but also associated with cultural and behavioral aspects as well. In terms of economic and technological activities, which are the direct cause of environmentally destructive behavior, individual beliefs and societal norms guide the development of these activities [2-3]. Therefore, the major objective of this 
article is to identify and determine the carbon emission of construction materials from selected case studies that contribute to the high emission of carbon within the Malaysian environment in order to identify the relationship between construction materials and its carbon emission.

\subsection{Energy Demand in Malaysia}

According to the Ninth Malaysia Plan, the overall national energy demand is expected to increase at an average rate of $6.3 \%$ annually from 2006 to 2010 . The industrial and transport sectors were reported as the major energy consumers constituting of $41.1 \%$ and $38.8 \%$ of the total energy demand in 2010 . Residential and commercial buildings accounted for $13 \%$ of total energy consumption and $48 \%$ of electricity consumption [4].

According to the Intergovernmental Panel on Climate Change (IPCC) fourth assessment's report, there are an abroad number of cost-effective technologies that have not yet been widely adopted, which can help in reducing the amount of GHGs emissions to a significant extent. These technologies include: highly efficient ventilation and cooling systems, high efficiency lighting and electrical appliances, passive solar design, insulation materials, solar water heaters, high-reflectivity building materials and multiple glazing. Rather than seek optimal building efficiency through the technologies available to reduce building energy demands, there has been an interest in developing renewable energy technologies that could meet the increasing demand of energy [5].

However, efforts are gearing up towards reducing energy use in building through the use of newer technologies and materials. Buildings having energy use savings up to $75 \%$ or higher through designs and operation stages of buildings as complete systems are being designed and built. Therefore, it is believed that there is a greater potential for better energy efficient building through construction of new building than retrofitting older ones.

\subsection{Building Construction and GHGs Emission}

The increased concentration of GHGs emission will lead to rise of global warming and drives what is called, climate change. Among GHGs emissions, carbon dioxide $\left(\mathrm{CO}_{2}\right)$ is the most important anthropogenic GHGs, and the global increases in $\mathrm{CO}_{2}$ concentration are due burning of fossil fuel and extensive uses of land [6].

According to Chan [7], the construction activities are considered the major contributor to environmental pollution, and the impact of construction industry produces undesirable remnants [8]. This includes the depletion of non-renewable resources, destruction of landscapes and creation of health and safety problems, both relating directly and indirectly to the people involved in this industry. In addition, the construction industry consumes large quantity of environmental resources and it is one of the largest polluters of the environment [9]. Currently, the world is facing the challenge of global warming and climate change issues. The $\mathrm{CO}_{2}$ is the most important by-product in the manufacture of building materials [10]. Furthermore, there are four sources of GHGs emission in construction of buildings, which are; the manufacture and transportation of building materials, energy consumption of construction equipment, energy consumption of processing resources and disposal of construction's waste [11].

\subsection{The Malaysian Constructions and GHGs}

In the worldwide, the building construction yearly consumes three billion tons of raw materials and produces $10 \%$ to $40 \%$ of solid waste stream in all countries [12]. In the United States, $70 \%$ of electricity consumption of buildings, $39 \%$ of energy use, $30 \%$ of waste output and $12 \%$ of all potable water consumption [13]. On the other hand, statistics show that in Malaysia, the buildings account for about $20 \%$ of the production of GHGs that comes in third after transportation $27 \%$ and industries $21 \%$ 
[14]. The materials used in buildings, which consist mainly of fossil fuels. In addition, $24 \%$ from the total $\mathrm{CO}_{2}$ comes from the construction industry in the country [15]. Furthermore, buildings are responsible for more than one third of total energy uses and associated GHGs emissions in society, both in developed and developing countries.

\subsection{Green Buildings}

Green Buildings are designed to reduce the negative effects of real estate development on the environment, human health and also aims at promoting sustainability of life. A carefully planned green building life-cycle during construction and operation of green building can "assure the healthiest possible environment while representing the most efficient and least disruptive use of land, water, energy and resources" [16].

The ideas behind the growing concern for green buildings is a response to the growing problems of pollution and environmental issues, increasing environmental awareness, acceptance of climate change, increasing energy cost, decreasing the consumption of natural resources and increasing demand for sustainability in building design and construction. Although buildings create serious problems for our environment, they can also serve as an essential path to the solution. Several studies have reported that buildings account for about $38 \%-50 \%$ of the GHGs emissions. They also found that one-third of the world's total energy is being consumed in the built environment while confirming that enhancement of demand and supply of green building could contribute up to $35 \%$ reduction of carbon emission. They argued further that adopting reflection techniques can achieve $30-50 \%$ reduction in total energy use; while green compliance could lead to $70 \%$ savings on waste output; and reduction of $40 \%$ of water usage [17-18].

Green buildings have been poised for early adoption in Malaysia due to recognition of the potential economic and environmental benefits. Published and available reports highlighted that there will be increasing demand for green buildings in relation to the growth among companies about environmental awareness and increase in corporate social responsibility as well as growing body of evidence demonstrating that green buildings make financial sense [19].

\subsection{Assessing Sustainability in Malaysia}

The Malaysian government has introduced some of energy efficiency measures in order to achieve sustainability goals like, the five-year development plans, which outline the government policies toward vision 2020, guidelines for buildings in improving their energy efficiency, road systems' improvement, the construction of both light rail and electrical systems. Even more strategies were adopted such as environmental regulations, planning and land uses in order to increase the intention of public awareness toward protection of the environment.

To construct a green buildings that can provide energy and water savings, a healthier indoor environment, better connectivity to public transport and the adoption of recycling and greenery in their projects is intended to promote sustainability in the built environment and raise awareness among developers, architects, engineers, planners, designers, contractors and the public about environmental issues [20].

\section{Research Methodology}

In this paper, the amount of carbon emission for each project has been extracted from Bill of Quantities (BQ) in the contract document. The conversions to tonnes are the density value, where it can relate the volume and weight for each material. The method used for the carbon equivalent is the boundary of cradle-to-gate method as the boundary condition are specified compared to cradle to grave. Then, the average of carbon emission for selected projects have been identified and compared accordingly. Figure 1 below explains the research methodology. 


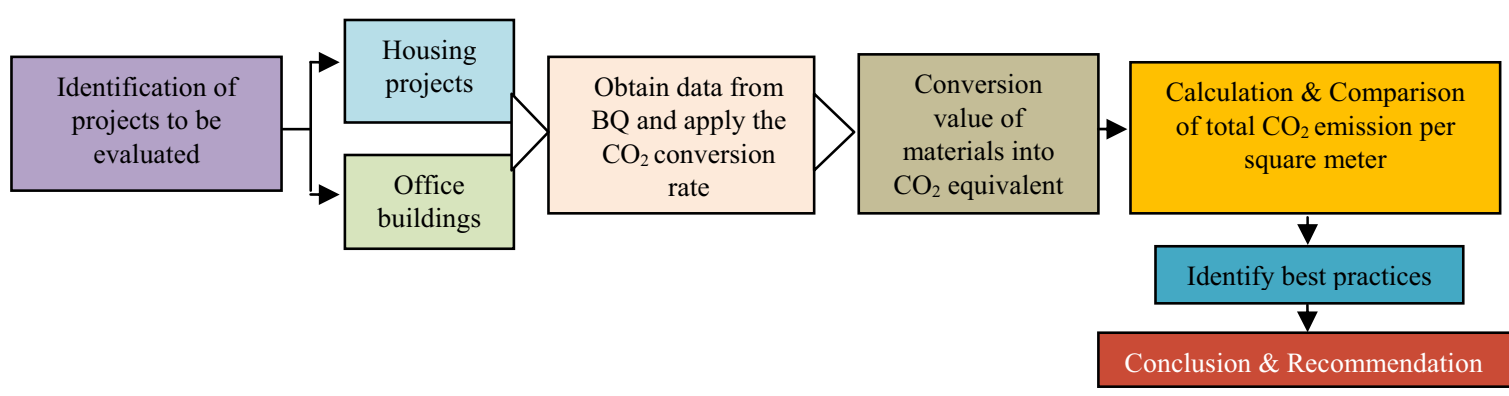

Fig. 1: The flowchart of research methodology

\section{Results and Discussions}

\subsection{Carbon emission from housing projects}

The quantification of carbon footprint is done by evaluating the selected Putrajaya Holdings' projects in Malaysia. The data is obtained from the BQ of the projects. In general, there are 26 units of intermediate double story houses (more environmental friendly) and 20 units of corner double storey house to be compared. In Table 1, the carbon emission of 26 unit intermediate double storey house has been classified into four major selected construction materials.

Table 1: Conversion of the material to $\mathrm{CO}_{2}$ equivalent for 26 units of intermediate double storey house (Project 1)

\begin{tabular}{|c|c|c|c|c|c|c|}
\hline Material & $\begin{array}{l}\text { Amount } \\
\text { from BQ }\end{array}$ & Unit & $\begin{array}{l}\text { Tonne conversion } \\
\quad\left(\text { tonnes } / \mathbf{m}^{3} \text { ) }\right.\end{array}$ & $\begin{array}{l}\text { Tonnes of } \\
\text { Material }\end{array}$ & $\begin{array}{c}\text { Tonnes } \mathrm{CO}_{2} / \text { tonnes } \\
\text { material }\end{array}$ & $\begin{array}{l}\mathrm{CO}_{2} \text { Emission } \\
\text { (tonnes) }\end{array}$ \\
\hline Concrete & 2271.49 & $\mathrm{M}^{3}$ & 2.2000 & 4997.28 & 0.2000 & 999.46 \\
\hline Steel & 141.62 & $\mathrm{Kg}$ & 8.0000 & 1132.99 & 1.8100 & 2050.71 \\
\hline Mortar & 26.47 & $\mathrm{M}^{2}$ & 2.2000 & 58.24 & 0.2100 & 12.23 \\
\hline Brick & 1080514 & $\mathrm{M}^{2}$ & 0.0024 & 2593.2 & 0.2000 & 518.65 \\
\hline
\end{tabular}

Table 2, classifies the carbon emission of 20 units corner double storey houses of each material that contributes to the $\mathrm{CO}_{2}$ equivalent to the project. The result shows that the Steel here still is the highest contributor followed by concrete.

Table 2: Conversion of the material to $\mathrm{CO}_{2}$ equivalent for 20 units of corner double storey house (Project 2)

\begin{tabular}{lcccccc}
\hline Material & $\begin{array}{c}\text { Amount } \\
\text { from BQ }\end{array}$ & Unit & $\begin{array}{c}\text { Tonne conversion } \\
\left(\text { tonnes } / \mathbf{m}^{\mathbf{3}} \text { ) }\right.\end{array}$ & Tonnes of Material & $\begin{array}{c}\text { Tonnes CO} \mathbf{C} / \text { tonnes } \\
\text { material }\end{array}$ & $\begin{array}{c}\mathbf{C O}_{2} \text { Emission } \\
\text { (tonnes) }\end{array}$ \\
\hline Concrete & 1918.20 & $\mathrm{M}^{3}$ & 2.2000 & 4220.04 & 0.2000 & 844.01 \\
Steel & 117.95 & $\mathrm{Kg}$ & 8.0000 & 943.56 & 1.8100 & 1707.85 \\
Mortar & 12.97 & $\mathrm{M}^{2}$ & 2.2000 & 28.52 & 0.2100 & 5.99 \\
Bricks & 704205 & $\mathrm{M}^{2}$ & 0.0024 & 1690.09 & 0.2000 & 338.02 \\
\hline \multicolumn{7}{c}{ TOTAL } \\
\hline
\end{tabular}

The result shows that the steel provides the highest amount of $\mathrm{CO}_{2}$ equivalent value, followed by concrete and bricks. It can be seen that in Figure 2, the two projects have a similar trend in which the concrete and steel has the highest contribution of carbon emission compared to all other materials. 


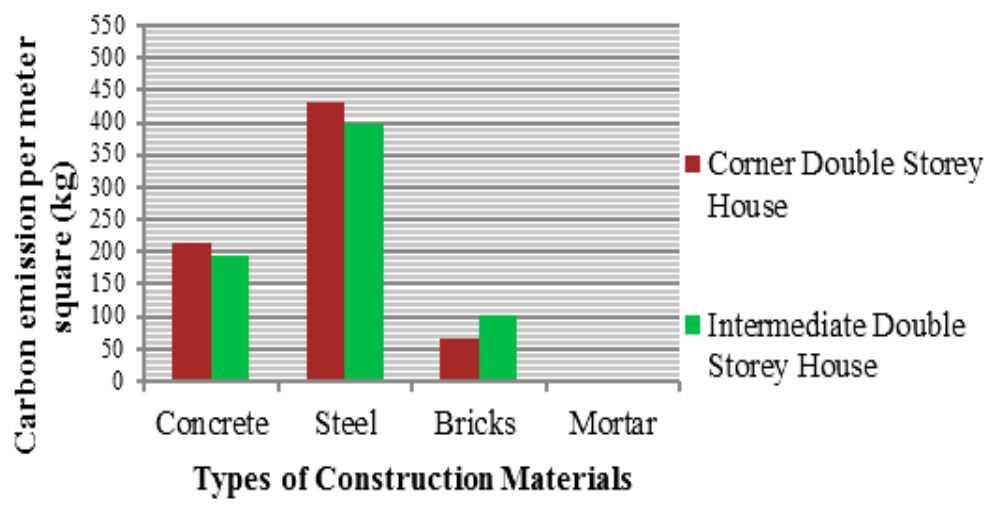

Fig. 2: Carbon emission from materials of housing projects

The amount varies of selected materials are dependant to the material usage. Therefore, the carbon dioxide equivalent value must be represented as accurately as possible. Table 3 presents the total carbon emission equivalent of each project per meter square.

Table 3: The $\left(\mathrm{kg} \mathrm{CO}_{2}\right)$ equivalent per square meter of selected housing projects

\begin{tabular}{cccc}
\hline Project & $\begin{array}{c}\mathrm{CO}_{2} \text { emission }\left(\mathrm{CO}_{2 \mathrm{e}}\right) \\
(\mathrm{kg})\end{array}$ & $\begin{array}{c}\text { Gross floor area (GFA) } \\
\left(\mathrm{m}^{2}\right)\end{array}$ & $\mathrm{CO}_{2}$ e per sqm. $\left(\mathrm{kgCO}_{2} / \mathrm{m}^{2}\right)$ \\
\hline H. Project 1 & 3581040 & 5130.3 & 698.01 \\
H. Project 2 & 2895862 & 3946.4 & 733.7 \\
\hline
\end{tabular}

Figure 3 shows the carbon emissions equivalent per square meter for sustainable (H. Project 1) and conventional housing (H. Project 2) projects. The values obtain for sustainable project is $698.01 \mathrm{~kg}$ $\mathrm{CO}_{2} / \mathrm{m}^{2}$, whereas conventional project gives values of $733.7 \mathrm{~kg} \mathrm{CO} / \mathrm{m}^{2}$, with the average of $715.8 \mathrm{~kg}$ $\mathrm{CO}_{2} / \mathrm{m}^{2}$. In terms of reduction percentage by comparing both sustainable and conventional housing projects, it is found that the sustainable housing project has a lower carbon footprint than conventional project by $4.8 \%$.

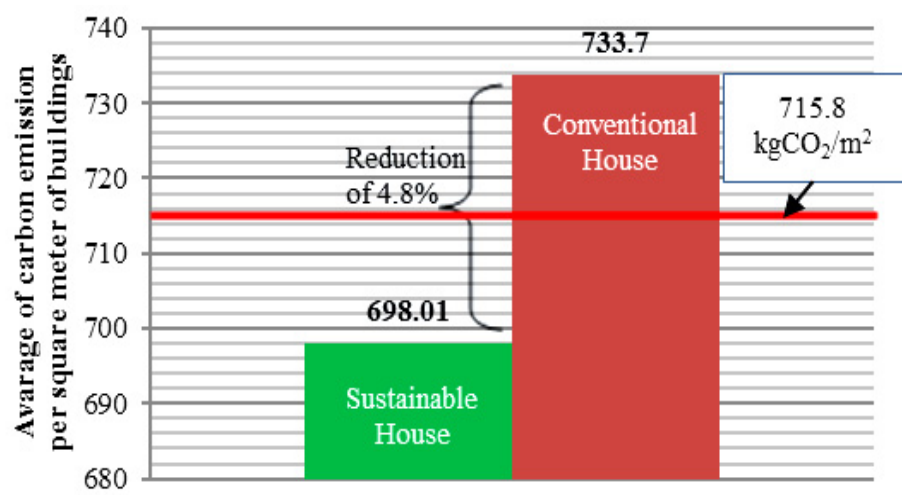

Fig. 3: The average carbon emission per square meter of housing projects

\subsection{Carbon emission from office buildings}

Table 4 classifies the office buildings into sustainable and conventional by evaluating the selected Putrajaya Holdings' projects. As shown in Figure 4, the usage of structural material for overall building area is much lower for sustainable buildings than the conventional buildings. It is 
found that the sustainable buildings have a lower carbon footprint than conventional buildings by $16.17 \%$. With the average of $333.98 \mathrm{~kg} \mathrm{CO} / \mathrm{m}^{2}$ as shown in Figure 5. Technically, sustainable buildings emit less carbon footprint than conventional buildings due to the efficiency in using building materials in construction activities for these green building projects.

Table 4: The $\mathrm{kg} \mathrm{CO}_{2}$ equivalent per square meter of selected office building projects

\begin{tabular}{cccc}
\hline Project & $\mathbf{C O}_{\mathbf{2}}$ emission $\left(\mathbf{C O}_{2} \mathbf{e}\right) \mathbf{( k g )}$ & $\mathbf{G F A ~}\left(\mathbf{m}^{2}\right)$ & $\begin{array}{c}\mathbf{C O}_{\mathbf{2}} \mathbf{e} \mathbf{~ p e r ~ s q m} . \\
\left(\mathbf{k g C O}_{\mathbf{2}} / \mathbf{m}^{2}\right)\end{array}$ \\
\hline Lot 2C2- Green & 20230195.753 & 53486 & $\mathbf{3 7 8 . 2 3 3}$ \\
Lot 4C11- Green & 29359701.612 & 77600 & $\mathbf{3 7 8 . 3 4 7}$ \\
Lot 348-Green & $21,481,540.82$ & 136636 & $\mathbf{1 5 7 . 2 1 6}$ \\
\hline Plot Z1-Conventional & 7287743.372 & 16362 & $\mathbf{4 4 5 . 3 9 6}$ \\
Loc 3C-Conventional & 12248705.43 & 29473 & $\mathbf{4 1 5 . 5 9 0}$ \\
411-G- Conventional & $19,872,828.68$ & 86758 & $\mathbf{2 2 9 . 1}$ \\
\hline
\end{tabular}

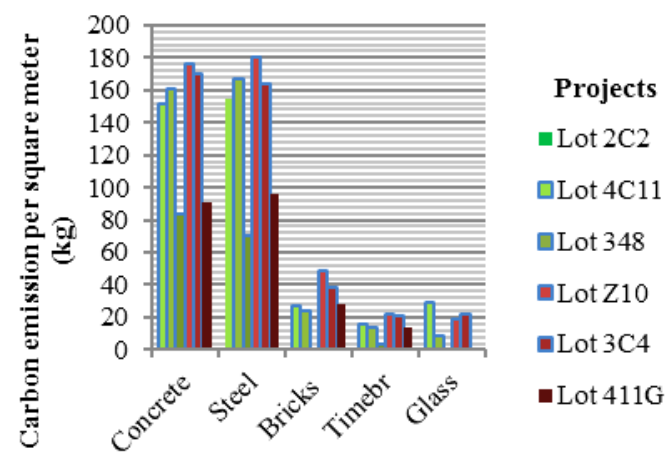

Types of Construction Materials

Fig. 4: Comparison of carbon emission of building materials $(\mathrm{kg})$ per $\mathrm{m}^{2}$ and the average $\mathrm{CO}_{2} / \mathrm{m}^{2}$

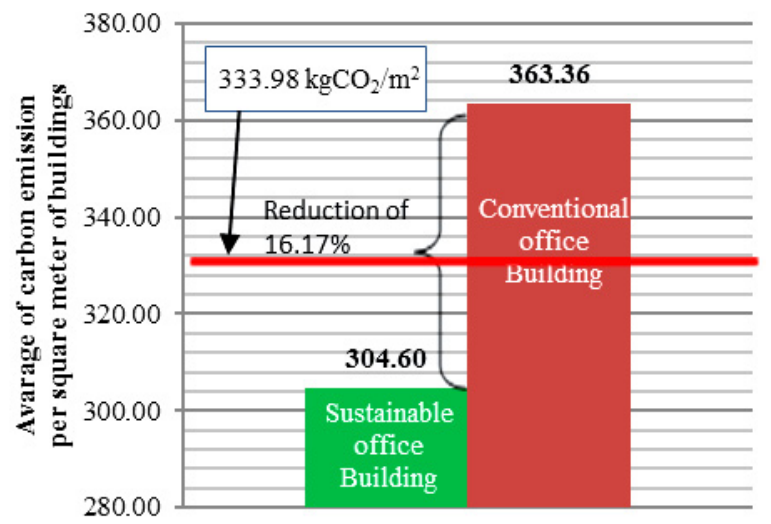

Fig. 5: Total average of carbon emission per $\mathrm{m}^{2}$ of each building

\section{Conclusion and Recommendations}

From the research done of the Stockholm Environment Institute (SEI), the average of GHGs emission by material type of an On-Site Construction House is approximately $660 \mathrm{~kg} \mathrm{CO} / 2 \mathrm{~m}^{2}$ of GHG emission per square meter. In comparison to the case study in this paper, the carbon emission is 715 $\mathrm{kg} \mathrm{CO} 2 \mathrm{e} / \mathrm{m}^{2}$. Thus, the housing project's carbon emission is relatively high. The value obtained for office buildings is less compared to that of conventional building by $16.17 \%$ reduction in comparison. 
These values differ because the construction of sustainable buildings used materials more efficiently than conventional buildings. It can be concluded that for further buildings construction's practice in terms of building materials and the amount of carbon emission is recommended to be below the red line $\left(715 \mathrm{~kg} \mathrm{CO} 2 \mathrm{e} / \mathrm{m}^{2}\right)$ for housing projects and $\left(333.98 \mathrm{Kg} \mathrm{CO} / \mathrm{m}^{2}\right)$ for office buildings and any values obtained above the red line is considered as not being able to adapt the good practice.

Choosing environmental-friendly materials would absolutely help in minimizing the depletion of natural resources including raw materials such as gravel and sand as well as energy and water used annually in the manufacturing \& construction process. This practice can be applied in choosing "green" structural materials. For example, in constructing sustainable building, instead of using ordinary cement, one can use 'green cement' in which is a combination of cement kiln dust (CKD) and class F Fly Ash. In addition, it is possible to reduce amount of steel and concrete to construct the building. This can actually be achieved by using lightweight materials such as light weight concrete so that the loading carried by the structural elements such as main beams and columns can be reduced significantly.

\section{References}

1. Nation Master Statistic, 2013. $\mathrm{CO}_{2}$ Emission by Country. Available at: http:/ www.nationmaster.com October, 19, [NOV, 2013].

2. Barley, S., 1986. Technology as an occasion for structuring: Evidence from observations of CT scanners and the social order of radiology departments. Administrative Science Quarterly 31: 78-108.

3. David, P., 1985. Clio and the economics of QWERTY. Economic History 75: 227-332.

4. EIB, 2008. Energy Information Bureau (EIB) Malaysia.

5. Hani, S.A., S. Kamaruzzaman, A. Mohamed, M.A.H. Ahmed and N.A. Ahmed, 2009. Experimental Study of Using Renewable Energy in Yemen. Australian Journal of Basic and Applied Sciences, 3(4): 4170-74.

6. Patermann, C., 1999. The fifth EU framework programme and its consequences for the construction industry. Journal of Building Research \& Information, 27(6), 412-418.

7. Chan, A., 2004. Key performance indicators for measuring construction success: Benchmarking, An International Journal, 11(2), 203-221, 2004.

8. Augenbroe, G., Pearce, A. R., 1998. Sustainable Construction in the United States of America A perspective to the year 2010 .

9. Ding, G. K., 2008. Sustainable construction-the role of environmental assessment tools. Journal of Environmental Management, 86(3), 451-464.

10. Buchanan, A. H., \& Honey, B. G. (1994). Energy and carbon dioxide implications of building construction. Journal of Energy and Buildings, 20, 205-217.

11. Yan H., Shen Q., Fan H., Wang Y., Zhang L., 2010. Green Gas Emission in Building Construction: A case study of one Peking in Hong Kong. Journal of Building and Environment, 45, $1-7$.

12. United Nations, 2007. Malaysia Initial National Communication: United Nations Framework Convention on Climate Change. Kuala Lumpur: Ministry of Science, Technology and the Environment.

13. IPCC, 2007. Climate Change: The Physical Science Basis, Geneva: Intergovernmental Panel on Climate Change.

14. Kibert C., 2002. Policy Instruments for Sustainable Built Environment. Journal of Land Use and Environmental Law,17(2), 379-394. 
15. Samad M. H., A. M. A. Rahman M. A., Ibrahim F., 2008. Green Performance Ratings for Malaysian Buildings with Particular Reference to Hotels. In Proc. of International Conf. on Environmental Research and Technology, Penang, Malaysia, 313-317.

16. Zeigler, P.M., 2012. What is a Green Building? And Fundamental Principles of Green Building and Sustainable Site Design. Governor's Green Government Council (GGGC) Pennsylvania.

17. US Green Building Council (USGBC) Washington (2003) Building Momentum: National Trends and Prospects for High-Performance Green Buildings.

18. GBI, 2010. GBI Assessment Criteria for NRNC. Green Building Index Sdn. Bhd: April 2012.

19. Godwin U., Maizon H., Afeez O., Kherun N., 2013. Review of Green Building Demand Factors for Malaysia. Journal of Energy Technologies and Policy. 3(11).

20. Chandranayagam D. 2013. Malaysia’s Green Building Index for Tropical Structures. 